\title{
Visualising Violence: The Articulation of Papuan Political Resistance on Social Media
}

\author{
Yuyun W.I. Surya \\ The University of Auckland \\ Auckland, New Zealand \\ ysur846@aucklanduni.ac.nz
}

\begin{abstract}
This paper examines how Papuans use Facebook to resist Indonesian hegemony and to express the political dissent. In particular, it aims to explore the extent to which Papuans document the violence and human rights abuse they experience on 'Orang Papua' Facebook group account, which debates the various form of state terrors. It also explores how members of Orang Papua Facebook group account use visual images to express their political resistance to provoke the world on human rights abuses in Papua. Multimodal discourse analysis is chosen as the method. This method offers a tool to collect and analyze data that is appropriate to study texts in social media. This paper concludes that members of Orang Papua group have developed the narratives of violence and occupation that coexist with narratives of political resistance. Image-making act can itself be a political act as images can implicitly diffuse political arguments. The use of visual images of violence are political but they are also aimed at articulating human rights violations. As members of this group become increasingly adept at using social media to get their story out, they use stories of human rights violation to attract more international attention.
\end{abstract}

Keywords-Visual Violence, Papua, Political resistance, Facebook

\section{INTRODUCTION}

Political struggle is a struggle over presence and visibility [1]. States, oppositional groups, and ordinary people are engaging in the political struggle through the image. They deliberately are using images to exert political influence. Thus, the visual image can be said as the heart of the political struggle where there is an endless process of images battling, reversing, erasing and replacing other images. According to Khatib [1], visual images are "a construct infused with meanings, attributes and projected perceptions". The desire to get rid of any image can be realized only through a new image. In fact, the key political moments in the last decade are mainly remembered as images, such as the collapse of the Twin Tower that marked the USA so-called war on terrorism, the Bouazizi's self-immolation that sparked the Tunisian revolution, the 1998's reformation in Indonesia and the current 212 movements against the blasphemy in Jakarta. The use of the visual image that engaged people in the political movement is maximized by the use of social media. Through its multimodal platforms, that is the ability of the medium to converge messages in the form of text, pictures, audio and video, social media becomes the one of latest option to create and distribute visual images for the sake of political goals.

This paper examines how Papuans use Facebook to resist Indonesian hegemony, express political dissent. In particular, it aims to explore the extent to which Papuans document the violence and human rights abuse they have experienced on Orang Papua Facebook group indicting the Indonesian state's culture of terror as well as explore how members of Orang Papua group use of visual images to express their political resistance by raising international awareness of human rights abuses in Papua. Understanding Papuans' social media activism is significant since Papuans are denied freedom of expression and sovereignty and are unable to rely upon mainstream media to represent their cultural and political interests. Therefore Papuans are increasingly using social media to make claims for independence from Indonesian rule, and expose human rights abuses.

Papua is one of the Indonesian regions where ethnic-based movement has been on the rise. The island of Papua is located in the easternmost part of Indonesia and comprised most of the western half of New Guinea. It is Indonesia's largest province with a low population density compare to other provinces in Indonesia. The current Indonesian government utilizes a security approach to criminalize free speech and peaceful dissent. They deploy military troops whose mission is to monitor, intimidate and conduct covert operations against Papuans. Activists are not allowed to have peaceful rallies. Books that discuss human rights violation and Indonesian military occupation in Papuan are banned. In 2016, over 3000 Papuans were arrested for participation in peaceful rallies. The lack of democratic space in Papua resulted in rising ethnic tensions and separatist activities. Papuans' struggle for self-determination is perceived as endangering the integrity of NKRI (the unitary state of the Republic of Indonesia). A program such as the transfer of Indonesian settlers, and the security approach to suppressing Papuans dissension support allegations that the Indonesian government has committed ethnic genocide against the Papuans.

Facebook was selected because of its interactive, multimodal and user-centered nature. The ubiquity of Facebook, coupled with the ease with which a group can be formed, makes it a convenient form of political expression. In addition, Facebook 
has become the most common entry to Papuan online activism [2]. It has been utilized to disseminate a wide variety of information relating to Papua. It provides a proper way to present news and views on Papua since the company imposes few political restrictions [3] and becomes the key plank of civil resistance strategy [2]. The Orang Papua group was selected due to its large number of members compared to other similar social media groups. To date, there are more than 80,000 members of the group. As this study is primarily concerned with the use of language in a specific context on social media site, that is the posts produced by members of Orang Papua group, this study employed a multimodal discourse analysis as the research method. Thus, Papuans have taken the opportunity to use Facebook as part of their political movement.

Papua was a military operations area from 1963 to 1998 and security operations continue to this day and torture is used to enforced submission. Furthermore, there have been marginalization in the economy, education sector, and bureaucracy. The experience of being treated as stupid and incapable become reasons for the struggle for separation and independence. Papuans' quest for self-determination seems to be in conflict with Indonesian nationalism. Instead of taking a "persuasive" approach that in most cases only become official rhetoric, the Indonesian government takes a repressive approach to conflicts in Papua. From the Indonesian government's perspective, separatist movements have always "threatened the totality of the unitary state of Indonesia" [4]. Violations of territorial sovereignty and integrity regarded as taboos by the Indonesian government that should be avoided at all cost, even if it means condoning repression of secessionists. Members of the Orang Papua group have visualized this ruthless repression to get an instant support through emotionally-triggered pictures of so-called the victims of Indonesian armed forces atrocities. Abusive Indonesian security forces have long served as a rallying point for Papuan separatists. Furthermore, Chauvel argues that the Papuan loathe the Indonesians as a direct consequence of the way in which Indonesians have despised and belittled the Papuans [4]. Papuans are simply thought of as possessions rather than as fellow-Indonesians [4]. Thus, it is not a surprise to find members of Orang Papua group exploited the images of bloodshed and tortured to articulate their hatred of Indonesian.

Facebook plays an important role for members of Orang Papua group to gain public visibility and shape public opinion. It offers places to post and share such shocking images as well as add captions and comments to contextualize the images that fit into Papuan political framework. Images of blood/tortured Papuans along with Indonesian military members with guns are posted aimed at showing random brutalization of Papuan civilians which often takes place in public places.

\section{RESEARCH METHOD}

Multimodal discourse analysis is chosen as the method. This method offers a tool to collect and analyze data that is appropriate to study texts in social media. Social media is 'multimodal' that insofar as it incorporates various modes including visual, audio, and moving images [4]. This method pays attention to specific aspects of the medium and situation allows us to interpret and understand the significance of social media data [5]. The main benefit of applying multimodal discourse to analyze social media text is it potentially include all multimodalities of communication on social media. In this study, the data--multimodal texts produced by members of the Orang Papua group were collected over a six-month period.

\section{RESEARCH RESULT}

Visual images as a form of expression of Indonesian violence were in fact used by Papuans long before the coming of the internet. Rutherford observes that in one village in Papua there is a mural painting featuring images such as a bleeding skull wearing special forces beret along with a portrait of traditional warriors [7]. It recalls the Indonesian state's deathly violence. The need to show and demonstrate the oppression has made the ability to communicate in visual forms is especially important for Papuans, who need to disseminate the importance of fighting against Indonesian government and reaching their political goal to become an independent nation. Thus the need to be recognized and be "seen" has made members of Orang Papua group put images central to Papua's political struggle. While it is estimated that between 100,000 and 500,000 Papuans have been killed under the Indonesian occupation, crimes against humanity committed by Indonesian security forces documented extensively elsewhere have been horrific and frequent, yet ignored. Since 1957, there was the institutionalization of violence due to the increasing role of the military in politics and administration in Indonesia.

Those who opposed the Indonesian government in the regions were regarded as 'animals and 'devils'. The posted images were used to prove and visualized this label, and at the same time put the Indonesian government as being cruel and abusive. Thus, the visual forms, especially emotionally provocative ones, do not only provide evidence of military/violence practices that have been done by the Indonesian government but also the useful and instant tool for political mobilization.

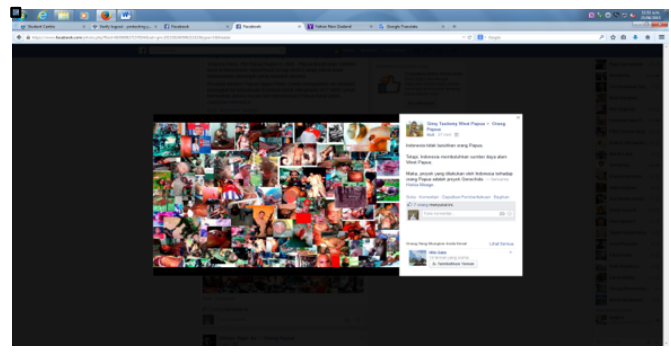

Fig.1. Mosaic pictures of tortured bodies

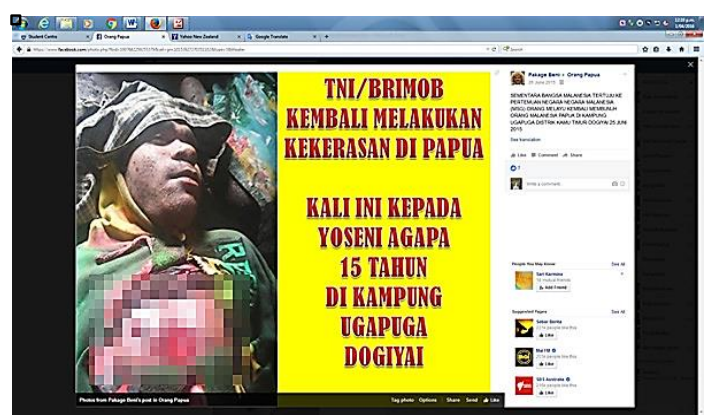

Fig. 2. TNI [Indonesian Armed Forces] has done this violence again 
The first post contains an image that visualized tortured bodies and bloodshed. The image that visualizes dozens of tortured dead bodies does not only imply that there is massive and systematically organized massacre happened in Papua but also implies that there is a lot of conflict in Papua. Tortured death bodies images are aimed at generating the broad and universalized emotional resonance of injustice frame. Furthermore, the civilian casualties showed in the mosaic picture above indicates the intention of the posted-message sender to show the gap between the Indonesian government's peace rhetoric and the unchanged heavy-handed response (military approach) in Papua.

The Indonesian government has promised to have the commitment to address the various human rights violations in Papua, include providing remedies for victims, and evaluating the security forces in the province. However, the government has not resolved any of the past human rights violations. The use of images of bloodied bodies can be seen as martyrs in Papua's struggle for freedom. The images can also function as evidence of atrocities since the pictures will not be found in mainstream media in Indonesia. In this sense, posted images in Orang Papua group become an issue intensifier, where members of the group highlight the issue of human rights abuse, blow up the reality and exacerbate it. Furthermore, these posts are part of an attempt to show the Indonesian government's involvement in human rights abuses and violence against its own citizens. In 2003, the Indonesian National Commission on Human Rights declared that the military was committed abuses in Papua, but no punishment applied to them.

In the Papuan context, bloody incidents are confronted with "a murky jigsaw consisting of rumors, facts, allegations, threats, political and economic interests" [8]. Rumors are considered as real as facts. Since there are only pictures without sources explaining who, why, when or how they have been murdered, one may doubt whether these Papuans who have been portrayed were all civilians and victims of the Indonesian's armed forces' violence due to their political activities. Yet members of the group who post these pictures add a caption such as shown in the first post. "Indonesian project in Papua is a genocide project", and second post. "TNI [Indonesian Armed Forces] has done this violence again". The second post indicates members of the group's attempt to contextualized the bloodied bodies image by adding a caption. The caption clearly identifies the bloodied body's identity (name, age, and location of the killing). The post that mentioned the victim's identity indicates an effort to convince other members of the group that the posted image is real. Furthermore, to prove that it is a real event with a real civilian victim, the post includes the reason behind the murder. It is written, "while Melanesians focused in MSG summit, Malays (Indonesians) are killing Melanesian Papuans" to indicate Indonesian government political movement by diverting attention from the effort to be part of MSG to the above issue.

The third and the fourth posts are examples of the images posted by members of Orang Papua group that emphasize the violence used by Indonesian armed forces to develop a visual narrative of resistance comprises of images of violence. The use of tortured bodies in the third post and a beaten man in the fourth post indicate an attempt to construct this narrative. These posts display the Indonesian armed forces to make the narrative stronger. The striking image of the officer who stomps his feet on the head of Papuan and injured Papuan become a visible evidence of the involvement of the Indonesian government in the brutality. The use of capital letters "WHY" and "BECAUSE" in the caption re-emphasizes the argument that the Papuans' resentment is as the result of the brutality.

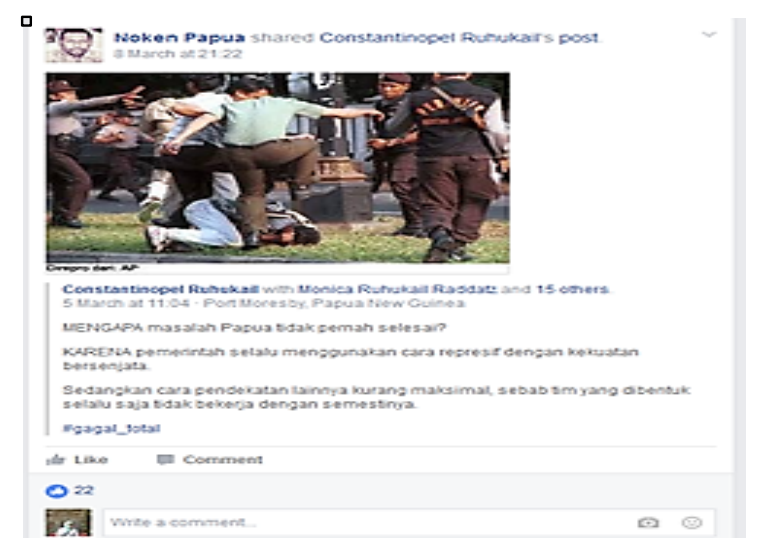

Fig. 3.. The state uses repressive approach through armed forces

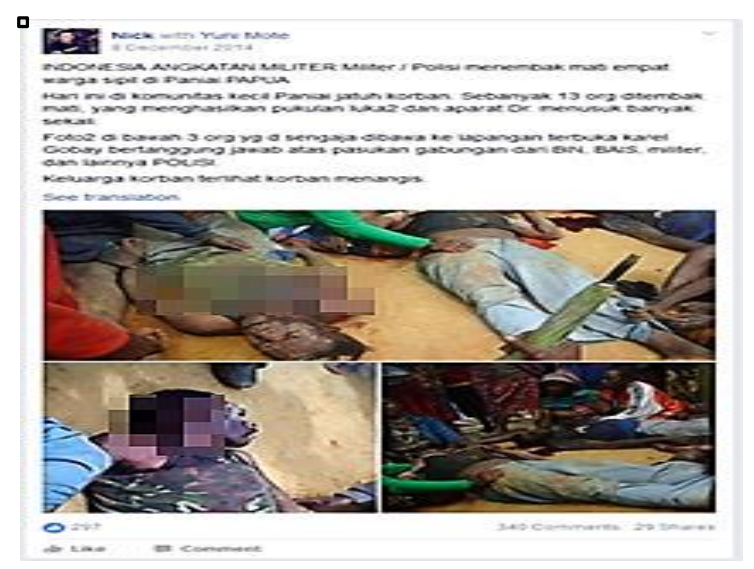

Fig. 4. Indonesian armed forces shot civilians in Paniai Papua

Through these posted-messages, members of Orang Papua group try and get most Papuans who are not politically active to engage through a widespread victimization and injustice. In this sense, images of tortured bodies have functioned as an expression of Papuans as victims and as a means to fight against the oppressive actors. Thus, this visually-dominant-posted pictures offer the justification of the struggle and reasons for Papuans to have political engagement and band together to reach the political goal.

The visual images posted by members of Orang Papua group emphasize the violence used by Indonesian armed forces to develop a visual narrative of resistance comprises of images of violence. The use of tortured bodies and a beaten man indicate an attempt to construct this narrative. Through these posted-messages, members of Orang Papua group try and get most Papuans who are not politically active to engage through a widespread victimization and injustice. In this sense, images 
of tortured bodies have functioned as an expression of Papuans as victims and as a means to fight against the oppressive actors. Thus, this visually-dominant-posted pictures offer the justification of the struggle and reasons for Papuans to have political engagement and band together to reach the political goal.

\section{CONCLUSION}

This paper concludes that members of Orang Papua group have developed the narratives of violence and occupation that coexist with narratives of political resistance as Khatib argues that the image-making act can itself be a political act as images can implicitly diffuse political arguments [1]. The use of visual images of violence are political but they are also aimed at articulating human rights violations. As members of this group become increasingly adept at using social media to get their story out, they use stories of human rights violation to attract more international attention. According to Macleod propagating the issue of severe human rights violations in Papua is much more dangerous than violent resistance because they have "reached the outside world." Through the Orang Papua Papuans Facebook users have created a contemporary dimension of Papuans' grievance [8]. While previously it is argued that their grievance is based on history, "the death of democracy" becomes their current grievance. This contemporary dimension is articulated through the issue of human rights violation and lack of freedom of expression. After the text edit has been completed, the paper is ready for the template. Duplicate the template file by using the Save As command, and use the naming convention prescribed by your conference for the name of your paper. In this newly created file, highlight all of the contents and import your prepared text file. You are now ready to style your paper; use the scroll down the window on the left of the MS Word Formatting toolbar.

\section{REFERENCES}

[1] L. Khatib, "Image Politics in the Middle East: the Role of the Visual in Political Struggle". London, UK: I.B. Tauris \& Co Ltd. 2013.

[2] D. Rutherford, "Nationalism and milleniarism in West Papua: Institutional power, interpretive practice, and the pursuit of Christian truth. In Nash, J. (ed). Social Movements: An Anthropological Reader, Carlton, Australia: Blackwell Publishing Ltd.. 2005.

[3] N. Chesterfield, "Free the people? Free the media! Broadcasting Papua's songs of freedom. In King, P., Elmslie, J., Webb-Gannon, C. (eds). Comprehending West Papua (29-36). [Online]. Avalaible: http://sydney.edu.au/arts/peace_conflict/practice/Comprehending\%20We st\%20Papua.pdf. October 2015.

[4] R. Chauvel, "Violence and governance in West Papua". In Coppel, C. (ed) Violent Conflict in Indonesia Analysis, representation, resolution, London, UK: Routledge Cookson, M. 2008. Papua Webs. Inside Indonesia Oct-Dec. [Online]. Avalaible: http://www.insideindonesia.org/papua-webs. 2016.

[5] M. Khosravinik, and J.W. Unger "Critical Discourse Studies and Social Media: Power, Resistance and Critique in Changing Media Ecologies". In Wodak, R. \& Meyer, M. (ed) Methods of Critical Discourse Studies 3rd edition. London, UK: Sage Publications Ltd. 2016.

[6] V. Eisenlauer, 2013. "A Critical Hypertext Analysis of Social Media: The True Colours of Facebook”, London, UK: Bloomsbury. 2016.

[7] J. Titifanue, J. Tarai, R. Kany and G. Finau, "From Social Networking to Activism: The Role of Social Media in the Free West Papua Campaign. Pacific studies 39(3)(255-281) [Online]. Avaliable: https://www.researchgate.net/publication/312594933_From_Social_Net working_to_Activism_The_Role_of_Social_Media_in_the_Free_West Papua_Campaign. 2017.

[8] J. MacLeod, "From the mountains and jungles to the villages and streets : Transitions from Violent to Nonviolent Resistance in West Papua. In Dudouet, V. (ed) Civil resistance and conflict transformation: transitions from armed to nonviolent struggle. New York, USA: Routledge. 2015. 